\title{
Zinc as a feed supplement and its impact on plasma cholesterol concentrations in breeding cocks
}

\author{
Tomáš Parák ${ }^{1,2}$, Eva Straková ${ }^{3}$ \\ ${ }^{1}$ Department of Human Pharmacology and Toxicology, Faculty of Pharmacy, \\ University of Veterinary and Pharmaceutical Sciences Brno \\ ${ }^{2}$ Brothers of Mercy Hospital Brno \\ ${ }^{3}$ Department of Nutrition, Zootechnics and Zoohygiene, Faculty of Veterinary Hygiene and Ecology, University \\ of Veterinary and Pharmaceutical Sciences Brno
}

Received January 17, 2011

Accepted September 13, 2011

\begin{abstract}
The aim of this work was to verify the impact of feed supplemented with selected inorganic and organic zinc compounds on the total cholesterol concentrations and other blood plasma indices in breeding cocks. A total of 250 RIR 05 breeding cocks, 9 weeks old, were used. The cocks were divided into 5 groups of 50 animals each (four experimental groups and one control group). Cocks were fed a commercial feed mixture specifically for breeding cocks, containing $30.4 \mathrm{mg} \cdot \mathrm{kg}^{-1}$ of zinc. The feed for experimental groups of cocks was fortified to $100 \mathrm{mg} \mathrm{Zn} \cdot \mathrm{kg}^{-1}$ : zinc sulphate in first group, zinc oxide in second group, fodder yeast (Minvital Zn) in third group and Bioplex $\mathrm{Zn}$ in fourth group. Blood samples for biochemical examination were taken from the basilic vein. The contents of total cholesterol (Chol), total proteins (TP), glucose (Glu), aspartate aminotransferase (AST), alanine aminotransferase (ALT), calcium (Ca), phosphorus $(\mathrm{P})$ and magnesium $(\mathrm{Mg})$ in blood plasma were spectrophotometrically measured using a biochemical analyser, Cobas EMira, and commercial kits (Biovendor a.s., Czech Republic). In the $15^{\text {th }}$ week of age, third and fourth groups showed a significant $(P \leq 0.05)$ and highly significant $(P \leq 0.01)$ decrease of total cholesterol in blood plasma compared to the control. In the $20^{\text {th }}$ and $25^{\text {th }}$ week of age, all of the experimental groups showed a significantand highly significant $(P \leq 0.01)$ decrease of total cholesterol in blood plasma compared to the control. Other monitored indices (total proteins, glucoses, aspartate aminotransferase, alanine aminotransferase, calcium, phosphorus and magnesium) did not reveal any significant changes between the experimental and the control groups. The presented work provides the first available experimental evidence regarding the impact of zinc supplementation on the cholesterol levels in blood plasma of breeding cocks.
\end{abstract}

\section{Supplementation, biochemical indices, zinc oxide, zinc sulphate, organic zinc forms}

Zinc is one of the trace elements necessary for the healthy development and functioning of living organisms. However, in tissue, its concentrations are not high. It is stated that the adult human body contains only 2-3 grams of zinc (Folin et al. 1994), with $90 \%$ of it deposited in muscle tissue and bones. The other $10 \%$ can be found in the prostate, liver, digestive tract, kidneys, skin, lungs, brain, heart and pancreas (Lichten and Cousins 2009). On the cellular level, $30-40 \%$ of the zinc is located in the nucleus, $50 \%$ in cytosol, and the rest in the membrane (Vallee and Valchuj 1993). Zinc is necessary for the proper functioning of many enzymatic systems, and the insulin system is probably the most important one. It also plays a significant role in various peptidases, esterases and dehydrogenases. It influences the immune system, DNA synthesis, cell proliferation, protein synthesis and the incorporation of iron into the haemoglobin. A deficiency of zinc can cause abnormal mental and physical growth in children. A zinc deficiency in adults can lead to weight loss, slower healing of wounds and memory deterioration (Wuehler et al. 2005). The recommended daily intake for pregnant women in the Czech Republic is $14 \mathrm{mg}$

Address for correspondence:

MUDr. Tomáš Parák, Ph.D.

Department of Human Pharmacology and Toxicology

Faculty of Pharmacy

University of Veterinary and Pharmaceutical Sciences Brno

Brno, Palackého 1/3, Czech Republic

E-mail: parakt@vfu.cz

http://www.vfu.cz/acta-vet/actavet.htm 
(Hronek 2004). For men, the U.S. Food and Drug Administration (FDA) recommends a daily intake of $15 \mathrm{mg}$.

The European Commission issued Regulation No. 1334/2003, which limits the maximum tolerable zinc levels in feed mixtures for livestock at $150 \mathrm{mg} \cdot \mathrm{kg}^{-1}$, and in animal breeding at $250 \mathrm{mg} \cdot \mathrm{kg}^{-1}$. Many authors have demonstrated the impact of zinc supplementation within several indices of the internal environment in birds (Kucuk et al. 2003; Sahin et al. 2005), mammals and humans (Gatto and Samman 1995; Hughes and Samman 2006). Its significance has also been stated in relation to various metabolic disorders as well as several diseases, such as Ischemic Heart Disease (IHD), dyslipidemia, hypertension, diabetes mellitus and obesity (Truswel 2003).

The aim of this work was to verify the impact of feed supplemented with selected inorganic and organic zinc compounds on total cholesterol levels and other blood plasma indices in breeding cocks.

\section{Materials and Methods}

A total of 250 RIR 05 breeding cocks, aged 9 weeks were selected for the experiment. The cocks were analogically divided (according to their live weight) into 5 groups (four experimental groups P1-P4 and one control group C) of 50 animals each, and were located in the experimental stable of the Department of Nutrition, Zootechnics and Zoohygiene, Faculty of Veterinary Hygiene and Ecology, University of Veterinary and Pharmaceutical Sciences Brno. The temperature in the experimental stable was $15-18{ }^{\circ} \mathrm{C}$ and the lighting schedule was as follows: $10^{\text {th }}$ to $19^{\text {th }}$ week, $8 \mathrm{~h}$ of light; $9 \mathrm{~h}$ in the $20^{\text {th }}$ week, $10 \mathrm{~h}$ in the $22^{\text {nd }}$ week and each following week $0.5 \mathrm{~h}$ of light was added until the $25^{\text {th }}$ week. Cocks were fed a commercial feed mixture specifically for cock breeding (supplier ZZN Pelhřimov, Czech Republic), containing $30.4 \mathrm{mg} \cdot \mathrm{kg}^{-1}$ of zinc $(\mathrm{Zn}-\mathrm{C})$. The feed was fortified to $100 \mathrm{mg} \mathrm{Zn} \cdot \mathrm{kg}^{-1}$ for the experimental groups: zinc sulphate $\left(\mathrm{ZnSO}_{4}\right.$; SigmaAldrich., Czech Republic) for group P1, zinc oxide (ZnO, Sigma-Aldrich) for group P2, fodder yeast Minvital $\mathrm{Zn}$ (Vitex, Biocel Paskov a.s., Czech Republic) for group P3 and Bioplex Zn (Alltech, USA) for group P4. The nutritional content of the feed mixture was verified analytically, and contained the following nutrients: $\mathrm{ME}_{\mathrm{N}}$ $11.6 \mathrm{MJ} \cdot \mathrm{kg}^{-1}$, crude protein $145.8 \mathrm{~g} \cdot \mathrm{kg}^{-1}$, threonine $4.8 \mathrm{~g} \cdot \mathrm{kg}^{-1}$, methionine $2.7 \mathrm{~g} \cdot \mathrm{kg}^{-1}$, lysine $6.6 \mathrm{~g} \mathrm{~g} \cdot \mathrm{kg}^{-1}$ and arginine $9.9 \mathrm{~g} \cdot \mathrm{kg}^{-1}$, fat $38.3 \mathrm{~g} \cdot \mathrm{kg}^{-1}$, fibre $58.9 \mathrm{~g} \cdot \mathrm{kg}^{-1}$, starch $435.6 \mathrm{~g} \cdot \mathrm{kg}^{-1}$, ash $105.6 \mathrm{~g} \cdot \mathrm{kg}^{-1}$, phosphorus $6.2 \mathrm{~g} \cdot \mathrm{kg}^{-1}$ and magnesium $5.28 \mathrm{~g} \cdot \mathrm{kg}^{-1}$, sodium $1.5 \mathrm{~g} \cdot \mathrm{kg}^{-1}$.

In the $10^{\text {th }}, 15^{\text {th }}, 20^{\text {th }}$ and $25^{\text {th }}$ week of the experiment, 10 cocks from each group were randomly selected. Blood samples for biochemical examination were taken from the basilic vein. The concentrations of total cholesterol (Chol), total proteins (TP), glucose (Glu), aspartate aminotransferase (AST), alanine aminotransferase (ALT), calcium $(\mathrm{Ca})$, phosphorus $(\mathrm{P})$ and magnesium $(\mathrm{Mg})$ in blood plasma were spectrophotometrically measured using a biochemical analyser, Cobas EMira, and commercial kits (Biovendor a.s., Czech Republic).

The results were processed using statistical software Unistat 5.1.; ANOVA was used to evaluate the data. Differences between the experimental and control groups at a significance level of $P \leq 0.05$ were considered significant, and $P \leq 0.01$ as highly significant.

\section{Results}

The experimental groups at 10 weeks age of breeding cocks did not reveal any significant changes in total cholesterol and other blood plasma indices when compared to the control group (Table 1).

At 15 weeks old the groups which were given the organic zinc forms P3 (Minvital) and P4 (Bioplex), showed a significant $(P \leq 0.05)$ and highly significant $(P \leq 0.01)$ decrease of total cholesterol in their blood plasma compared to control group. Other blood plasma indices in the experimental groups did not reveal any significant changes compared to the control group (Table 1).

In the $20^{\text {th }}$ and $25^{\text {th }}$ week of age, cocks of all experimental groups showed a highly significant $(P \leq 0.01)$ decrease of total cholesterol concentrations in the blood plasma compared to control group, regardless of the zinc form that had been supplemented. Other indices monitored in the experimental groups did not reveal any significant changes compared to the control group (Table 1). 
Table 1. Biochemical indices of the blood plasma of cocks 10-25 weeks old (mean \pm SD)

\begin{tabular}{|c|c|c|c|c|c|c|c|c|}
\hline \multicolumn{9}{|c|}{ Biochemical indices } \\
\hline & $\begin{array}{c}\text { Chol } \\
\left(\mathrm{mmol} \cdot 1^{-1}\right)\end{array}$ & $\begin{array}{c}\text { TP } \\
\left(\mathrm{g} \cdot \mathrm{l}^{-1}\right)\end{array}$ & $\begin{array}{c}\text { Glu } \\
\left(\mathrm{mmol} \cdot \cdot^{-1}\right)\end{array}$ & $\begin{array}{c}\text { AST } \\
\left(\mu \mathrm{kat} \cdot \mathrm{l}^{-1}\right)\end{array}$ & $\begin{array}{c}\text { ALT } \\
\left(\mu \mathrm{kat} \cdot \mathrm{l}^{-1}\right)\end{array}$ & $\begin{array}{c}\mathrm{Ca} \\
\left(\mathrm{mmol} \cdot{ }^{-1}\right)\end{array}$ & $\begin{array}{c}\mathrm{P} \\
\left(\left.\mathrm{mmol} \cdot\right|^{-1}\right)\end{array}$ & $\begin{array}{c}\mathrm{Mg} \\
\left(\mathrm{mmol} \cdot \mathrm{l}^{-1}\right)\end{array}$ \\
\hline \multicolumn{9}{|c|}{$10^{\text {th }}$ week } \\
\hline \multirow[t]{2}{*}{$\mathrm{C}$} & 3.19 & 31.48 & 14.92 & 0.80 & 0.019 & 2.62 & 2.03 & 0.78 \\
\hline & \pm 0.884 & \pm 3.098 & \pm 1.213 & \pm 0.041 & \pm 0.005 & \pm 0.189 & \pm 0.174 & \pm 0.054 \\
\hline \multirow[t]{2}{*}{$\mathrm{P} 1$} & 2.79 & 31.41 & 14.89 & 0.84 & 0.027 & 2.72 & 1.99 & 0.80 \\
\hline & \pm 0.523 & \pm 4.712 & \pm 0.992 & \pm 0.047 & \pm 0.014 & \pm 0.226 & \pm 0.113 & \pm 0.052 \\
\hline \multirow[t]{2}{*}{ P2 } & 2.99 & 32.25 & 14.34 & 0.85 & 0.025 & 2.62 & 1.99 & 0.77 \\
\hline & \pm 0.468 & \pm 4.845 & \pm 0.706 & \pm 0.059 & \pm 0.013 & \pm 0.208 & \pm 0.129 & \pm 0.045 \\
\hline \multirow[t]{2}{*}{ P3 } & 2.65 & 33.28 & 15.23 & 0.82 & 0.028 & 2.60 & 1.97 & 0.79 \\
\hline & \pm 0.241 & \pm 5.590 & \pm 1.282 & \pm 0.034 & \pm 0.013 & \pm 0.186 & \pm 0.182 & \pm 0.063 \\
\hline \multirow[t]{2}{*}{ P4 } & 2.72 & 34.40 & 15.18 & 0.87 & 0.016 & 2.63 & 2.00 & 0.81 \\
\hline & \pm 0.283 & \pm 4.870 & \pm 0.796 & \pm 0.034 & \pm 0.005 & \pm 0.279 & \pm 0.230 & \pm 0.042 \\
\hline \multicolumn{9}{|c|}{$\overline{15^{\text {th }} \text { week }}$} \\
\hline \multirow[t]{2}{*}{$\overline{\mathrm{C}}$} & 3.30 & 30.07 & 12.27 & 0.77 & 0.081 & 2.62 & 2.76 & 0.85 \\
\hline & \pm 0.467 & \pm 3.504 & \pm 1.165 & \pm 0.074 & \pm 0.016 & \pm 0.122 & \pm 0.550 & \pm 0.053 \\
\hline \multirow[t]{2}{*}{ P1 } & 2.92 & 31.90 & 12.67 & 0.76 & 0.171 & 2.57 & 2.37 & 0.81 \\
\hline & \pm 0.377 & \pm 3.191 & \pm 0.721 & \pm 0.041 & \pm 0.288 & \pm 0.193 & +0.362 & \pm 0.079 \\
\hline \multirow[t]{2}{*}{ P2 } & 2.97 & 29.96 & 12.92 & 0.75 & 0.088 & 2.60 & 2.56 & 0.86 \\
\hline & \pm 0.278 & \pm 2.879 & \pm 1.191 & \pm 0.032 & \pm 0.025 & \pm 0.158 & \pm 0.531 & \pm 0.065 \\
\hline \multirow[t]{2}{*}{ P3 } & $2.84 *$ & 29.81 & 12.00 & 0.77 & 0.075 & 2.57 & 3.28 & 0.89 \\
\hline & \pm 0.362 & \pm 2.690 & \pm 1.235 & \pm 0.039 & \pm 0.021 & \pm 0.122 & \pm 0.888 & \pm 0.054 \\
\hline \multirow[t]{2}{*}{ P4 } & $2.02 * *$ & 29.78 & 12.92 & 0.77 & 0.072 & 2.57 & 2.44 & 0.82 \\
\hline & \pm 0.502 & \pm 2.095 & \pm 0.805 & \pm 0.046 & \pm 0.024 & \pm 0.092 & +0.440 & \pm 0.069 \\
\hline \multicolumn{9}{|c|}{$20^{\text {th }}$ week } \\
\hline \multirow[t]{2}{*}{$\mathrm{C}$} & 3.44 & 31.07 & 12.68 & 0.75 & 0.091 & 2.63 & 1.88 & 0.90 \\
\hline & \pm 0.412 & \pm 5.416 & \pm 1.023 & \pm 0.080 & \pm 0.027 & \pm 0.129 & \pm 0.539 & \pm 0.056 \\
\hline \multirow[t]{2}{*}{ P1 } & $2.65 * *$ & 30.11 & 12.98 & 0.71 & 0.063 & 2.70 & 1.58 & 0.91 \\
\hline & \pm 0.429 & \pm 5.427 & \pm 1.228 & \pm 0.086 & \pm 0.043 & \pm 0.137 & \pm 0.263 & \pm 0.062 \\
\hline \multirow[t]{2}{*}{ P2 } & $2.23 * *$ & 30.40 & 13.14 & 0.70 & 0.102 & 2.57 & 1.62 & 0.88 \\
\hline & \pm 0.418 & \pm 1.519 & \pm 0.604 & \pm 0.084 & \pm 0.030 & \pm 0.159 & \pm 0.258 & \pm 0.058 \\
\hline \multirow[t]{2}{*}{ P3 } & $2.14 * *$ & 30.17 & 12.71 & 0.76 & 0.102 & 2.60 & 1.65 & 0.92 \\
\hline & \pm 0.215 & \pm 4.011 & \pm 1.004 & \pm 0.172 & \pm 0.029 & \pm 0.119 & \pm 0.158 & \pm 0.072 \\
\hline \multirow[t]{2}{*}{ P4 } & $2.02 * *$ & 33.21 & 13.07 & 0.72 & 0.086 & 2.82 & 1.84 & 0.90 \\
\hline & \pm 0.138 & \pm 5.204 & \pm 1.002 & \pm 0.073 & \pm 0.013 & +0.278 & \pm 0.702 & \pm 0.060 \\
\hline \multicolumn{9}{|c|}{$25^{\text {th }}$ week } \\
\hline \multirow[t]{2}{*}{$\overline{\mathrm{C}}$} & 3.25 & 31.96 & 13.30 & 1.10 & 0.08 & 2.58 & 1.66 & 0.95 \\
\hline & \pm 0.462 & \pm 7.548 & \pm 1.126 & \pm 0.1405 & \pm 0.029 & \pm 0.162 & \pm 0.544 & \pm 0.081 \\
\hline \multirow[t]{2}{*}{ P1 } & $2.20 * *$ & 35.28 & 12.95 & 1.05 & 0.17 & 2.70 & 1.29 & 0.93 \\
\hline & \pm 0.426 & \pm 3.505 & \pm 0.714 & \pm 0.1085 & \pm 0.202 & \pm 0.122 & \pm 0.360 & \pm 0.033 \\
\hline $\mathrm{P} 2$ & $2.22 * *$ & 33.41 & 12.74 & 1.09 & 0.076 & 2.82 & 1.42 & 0.91 \\
\hline & \pm 0.346 & \pm 4.817 & \pm 1.132 & \pm 0.082 & \pm 0.038 & \pm 0.132 & \pm 0.473 & \pm 0.080 \\
\hline P3 & $2.17 * *$ & 30.11 & 12.47 & 0.94 & 0.138 & 2.62 & 1.70 & 0.95 \\
\hline & \pm 0.591 & \pm 4.414 & \pm 1.391 & \pm 0.221 & \pm 0.182 & \pm 0.186 & \pm 0.501 & \pm 0.032 \\
\hline P4 & $2.19 * *$ & 32.80 & 12.94 & 0.99 & 0.062 & 2.75 & 1.49 & 0.92 \\
\hline & \pm 0.392 & \pm 4.833 & \pm 1.617 & \pm 0.141 & \pm 0.033 & \pm 0.133 & \pm 0.270 & \pm 0.054 \\
\hline
\end{tabular}

${ }^{*} P \leq 0.05,{ }^{* *} P \leq 0.01$, Chol - cholesterol; TP - total proteins; Glu-glucose; AST - aspartate aminotransferase; ALT - alanine aminotransferase; $\mathrm{Ca}$ - calcium, $\mathrm{P}$ - phosphorus; $\mathrm{Mg}$ - magnesium

$\mathrm{Cl}$ - control group, P1 - zinc sulphate $\left(\mathrm{ZnSO}_{4}\right)$, P2 - zinc oxide (ZnO), P3 - Minvital Zn, P4 - Bioplex Zn. 


\section{Discussion}

A great part of published works dealing with the influence of zinc on the internal environment and the biochemical indices of blood and health disorders has its origin in the area of human medicine. A placebo-controlled, double-blind randomized trial, which included 3,640 humans, was performed. It revealed that concentrations of plasma cholesterol are influenced by zinc ( $\mathrm{ZnO})$ supplementation $\left(80 \mathrm{mg}^{-d a y^{-1}}\right)$, either alone or in combination with copper or vitamins (Gensler et al. 2002). The decrease of cholesterol levels in blood plasma was also achieved in older populations, where zinc intake or serum zinc concentrations are lower than recommended, and they were provided zinc supplements in the amount of 20-53 $\mathrm{mg} \cdot \mathrm{day}^{-1}$ (Boukaiba et al. 1993).

The above results are supported by data from many researches in the area of veterinary medicine. The anti-atherogenic effect of zinc in hypercholesterolemic rabbits was reported (Ren et al. 2006; Rashtchizadeh et al. 2008). Zinc deficiency caused increased plasma lipid levels and an increased risk of cardiovascular diseases in LDL receptor knock-out mice. Mice with zinc-deficient diets exhibited increased cholesterol and triglycerides levels in blood plasma (Reiterer et al. 2005). Bolkent et al. (2006) proved the protective effect of zinc supplementation on lipid metabolism indices (total lipids, cholesterol, HDLcholesterol) in laboratory rats with streptozotocin-induced type 1 diabetes.

In our study, a significant decrease in the levels of total cholesterol in the blood plasma of breeding cocks was found in case of feed mixtures supplemented with zinc, to the amount of $100 \mathrm{mg} \cdot \mathrm{kg}^{-1}$ in all the used forms of zinc (organic and inorganic). Our results confirmed previous findings, which proved the positive impact of zinc on lipid metabolism indices. Herzig et al. (2009) proved that there was a significant decrease of plasma cholesterol in their experiment involving the administering of high amounts of zinc to chicken broilers. Aksu et al. (2010) also reported the decrease of total and LDL cholesterol, combined with the increase in HDL cholesterol in chickens' blood plasma, when the feed mixtures were supplemented with organic complexes of zinc, copper and manganese. However, Kucuk et al. (2008) did not confirm any significant changes in the concentrations of total cholesterol, triglycerides and glucose when supplementing $30 \mathrm{mg}$ of $\mathrm{Zn}$ per $1 \mathrm{~kg}$ of a feed mixture.

A significant decrease of the concentrations of total cholesterol in blood plasma of breeding cocks was found in case of supplementing feeding mixtures with zinc to the amount of $100 \mathrm{mg} \cdot \mathrm{kg}^{-1}$ in all used forms (organic and inorganic). It confirms the previous findings, which prove the positive impact of zinc on the lipid metabolism indices. The faster onset of the effects of organic zinc forms, after two weeks of administering, is most likely connected with the higher biological availability of elements bound in organic compounds compared to inorganic forms (Cao et al. 2003; Mantovani et al. 2010; Petrovic et al. 2010).

The impact of zinc on other monitored blood plasma indices in breeding cocks was not found in our study; the similar results were obtained by Bonham et al. (2003). The presented work provides the first available experimental evidence regarding the impact of zinc supplementation on the cholesterol concentrations in blood plasma of breeding cocks.

\section{Acknowledgements}

Financial support from the Ministry of Education, Youth, and Sports of the Czech Republic (Grant No MSMT $6215712402)$ is gratefully acknowledged.

\section{References}

Aksu DS, Aksu, T, Ozsoy, B 2010: The effects of lower supplementation levels of organically complexed minerals (zinc, copper and manganese) versus inorganic forms on haematological and biochemical parameters in broiler. Kafkas Univ Vet Fak 16: 553-559 
Bolkent S, Yanardag R, Bolkent S, Mutlu O, Yildirim S, Kangawa K, Minegishi Y, Suzuki H 2006: The effect of zinc supplementation on ghrelin-immunoreactive cells and lipid parameters in gastrointestinal tissue of streptozotocin-induced female diabetic rats. Mol Cell Biochem 286: 77-85

Bonham M, O’Connor JM, McAnena LB, Walsh PM, Downes CS, Hannigan BM, Strain JJ 2003: Zinc supplementation has no effect on lipoprotein metabolism, hemostasis, and putative indices of copper status in healthy men. Biol Tr Elem Res 93: 75-86

Boukaiba N, Flament C, Acher S, Chappuis P, Piau A, Fusselier M, Dardenne M, Lemonnier D 1993: A physiological amount of zinc supplementation: effects on nutritional, lipid, and thymic status in an elderly population. Am J Clin Nutr 57: 566-572

Cao J, Henry PR, Davis SR, Cousins RJ, Miles RD, Littell RC, Ammerman CB 2003: Relative bioavailability of organic zinc sources based on tissue zinc and metallothionein in chicks fed conventional dietary zinc concentrations. Anim Feed Sci Technik 101: 161-170

Folin M, Contiero E, Vaselli GM 1994: Zinc content of normal human serum and its correlation with some hematic parameters. BioMetals 7: 75-79

Gensler G, Gore-Langton R, Kurinij N, et al. 2002: The effect of five-year zinc supplementation on serum zinc, serum cholesterol and hematocrit in persons randomly assigned to treatment group in the age-related eye disease study. J Nutr 132: 697-702

Herzig I, Navratilova M, Totusek J, Suchy P, Vecerek V, Blahova J, Zraly Z 2009: The effect of humic acid on zinc accumulation in chicken broiler tissues. Czech J Anim Sci 54: 121-127

Hronek M 2004: Women's nutrition during pregnancy and lactation. Maxdorf Praha: 309

Hughes S, Samman S 2006: The effect of zinc supplementation in humans on plasma lipids, antioxidant status and thrombogenesis. J Am Coll Nutr 25: 285-291

Kucuk O, Sahin N, Sahin K 2003: Supplemental zinc and vitamin A can alleviate negative effects of heat stress in broiler chickens. Biol Trace Elem Res 94: 225-235

Kucuk O, Kahraman A, Kurt I, Yildiz N, Onmaz AC 2008: A combination of zinc and pyridoxine supplementation to the diet of laying hens improves performance and egg quality. Biol Trace Elem Res 126: 165-175

Lichten LA, Cousins RJ 2009: Mammalian zinc transporters: nutritional and physiologic regulation. Annu Rev Nutr 29: $153-176$

Mantovani A, Frazzoli C, Cubadda F 2010: Organic forms of trace elements as feed additives: Assessment of risks and benefits for farm animals and consumers. Pure Appl Chem 82: 393-407

Petrovic V, Nollet L, Kovac G 2010: Effect of dietary supplementation of trace elements on the growth performance and their distribution in the breast and thigh muscles depending on the age of broiler chickens. Acta Vet Brno 79: 203-209

Rashtchizadeh N, Ettehad S, Disilvestro RA, Mahdavi R 2008: Antiatherogenic effects of zinc are associated with copper in iron-overloaded hypercholesterolemic rabbits. Nutr Res 28: 98-105

Reiterer G, Macdonald R, Browning Jd, Morrow J, Matveev SV, Daugherty A, Smart E, Toborek M, Hennig B 2005: Zinc deficiency increases plasma lipids and atherosclerotic markers in LDL-receptor-deficient mice. J Nutr 135: 2114-2118

Ren M, Rajendran R, Ning P, Tan Kwong Huat B, Choon Nam O, Watt F, Jenner A, Halliwell B 2006: Zinc supplementation decreases the development of atherosclerosis in rabbits. Free Radic Biol Med 41: 222-225

Sahin K, Smith MO, Onderci M, Sahin N, Gursu MF, Kucuk O 2005: Supplementation of zinc from organic or inorganic source improves performance and antioxidant status of heat-distressed quail. Poult Sci 84: 882-887

Truswell AS 2003: ABC of Nutrition, 4th ed. London: BMJ

Vallee, BL, Falchuk, KH 1993: The biochemical basis of zinc physiology. Physiol Rev 73: 79-118

Wuehler SE, Peerson JM, Brown KH 2005: Use of national food balance data to estimate the adequacy of zinc in national food suplies: methodology and regional estimates. Public Health Nutr 8: 812-819 